\title{
Chromosomal Studies of Two Populations of Peromyscus difficilis felipensis (Rodentia: Muridae)
}

\author{
Carolina Müdespacher-Ziehl, Reyes Espiritu-Mora, \\ Matías Martínez-Coronel and Salvador Gaona \\ Departamento de Biología, Universidad Autónoma Metropolitana-Iztapalapa. Apdo. Postal 55-535, México D.F.
}

Received March 22, 2005; accepted May 18, 2005

\begin{abstract}
Summary This study evaluated and compared the chromosomes of 2 populations of Peromyscus difficilis felipensis which has a broad but discontinuous distribution. One population occurs throughout the central highlands of Mexico, $2000 \mathrm{~m}$ above sea level, where the population range extends through the States of Mexico and Morelos; the second population is found in a locality called Cerro San Felipe, State of Oaxaca. The chromosomes were obtained from bone marrow cells, and their classification is described here. The diploid chromosome number $(2 n)$ found is 48 and the fundamental number ( $\mathrm{fn}$ ) is 76 for both populations. The principal differences reside in one pair of the morphology of biarmed chromosomes. The chromosomic formula for the population in the States of Mexico and Morelos is $1 \mathrm{M}+1 \mathrm{SM}+13 \mathrm{ST}+8 \mathrm{~T}$, and for the population in the southeast of Oaxaca is $2 \mathrm{M}+13 \mathrm{ST}+8 \mathrm{~T}$. In both populations, the $\mathrm{X}$ chromosome is subtelocentric and the $\mathrm{Y}$ chromosome is metacentric. Several comparisons with other subspecies are presented here, as well as the description of a karyotype of Peromyscus difficilis felipensis which is different from other reported subspecies.
\end{abstract}

Key words Karyotpe, Peromyscus, Rodentia.

Peromyscus difficilis extends from northern Colorado southward into Oaxaca, and comprises 8 subspecies, but only 6 occur in Mexico: P. penicillatus, petricola, difficilis, amplus, felipensis and saxicola (Hoffmeister and de la Torre 1961, Carleton 1989, Hall 1981).

P. d. felipensis is characterized by the following: a large body and tail, large hind foot, large skull (the largest of all subspecies), long nasals, fairly long tooth-rows, a broad braincase and a blackish color suffused with silver. It differs from $P . d$. amplus in that it has a much darker color and a large skull size; however, $P$. $d$. amplus has a contrasting karyotype and its habitat is rocky (Arellano-Meneses et al. 2000). P. $d$. felipensis is the darkest of all subspecies and inhabits the highest altitudes.

The extent of $P$. $d$. felipensis is discontinuous. This is interesting to note when comparing the karyotype of the population that occurs throughout the central highlands of Mexico, $2000 \mathrm{~m}$ above sea level, where the population extends through the States of Mexico and Morelos, with the karyotype of the second population which is distributed in a locality called Cerro San Felipe, State of Oaxaca.

Comparison reveals that specimens of $P . d$. felipensis from Oaxaca and those from central Mexico are quite similar in color, skull size, proportions, and shape. If both population groups (Mexico-Morelos and Oaxaca) are truly of the same subspecies, geographical continuity must have been achieved at one time by way of the narrow corridor of highlands connecting central Mexico and Oaxaca. We felt, as did Hoffmeister and de la Torre 1961, that these 2 populations should be studied for several reasons: the southern population actually belongs to a different stock, but reacts in a similar manner to comparable environmental conditions as does the central population; also, both populations are derived from the same stock (possibly P. amplus-like) and thus represent parallel adaptations by different segments of a single stock which evolved in response to new environmental conditions that resembled the earlier ones. 
P. difficilis is one of the species of the genus which shows cytological polymorphism. Of the 6 specimens analyzed, there is no standard karyotype for this species (Hsu and Arrighi 1968). Only $P$. d. amplus has been described and the others have been reported to some degree. The purpose of this paper is to present the karyotype of $P$. $d$. felipensis and to indicate differences that exist between the central and southern populations, besides making a comparison between $P$. $d$. felipensis and $P . d$. amplus.

\section{Materials and methods}

Eight adults ( 4 female and 4 male) $P$. $d$. felipensis were collected in a wet oak-pine forest using Sherman traps from the following localities in central Mexico: Santiago Cuautenco, $4 \mathrm{~km}$ north-east of Amecameca, Estado de México; and Lagunas de Zempoala, Huitzilac, Morelos. The southeastern locality is in Sierra Norte, Santa Catarina Ixtepeji $17^{\circ} 11^{\prime \prime} \mathrm{N}$ and $96^{\circ} 38^{\prime \prime} \mathrm{W}, 2901 \mathrm{~m}$ a.s.1. (a National Protected Area known as La Cumbre) in an oak-pine forest in Oaxaca, Mexico. Voucher specimens were deposited as museum specimens in the mammal collection of the Universidad Autónoma Metropolitana Iztapalapa.

Metaphase chromosome spreads were obtained from bone marrow with the colchicine-hytpotonic method of Baker and Qumsiyeh (1988). Fifty fields on 15 chromosome slides were examined to determine the diploid number $(2 n)$ of each specimen examined. Conventional karyotypes were prepared from photographs of selected metaphase spreads. Chromosomes were classified on the basis of centromere position following Levan et al. (1964).

\begin{tabular}{cccc}
\hline \hline Classification & PB & IC & D \\
\hline $\mathrm{M}$ & $1.00-1.67$ & $37.50-50.00$ & $0.00-2.50$ \\
$\mathrm{SM}$ & $1.67-3.00$ & $25.00-37.50$ & $2.50-5.00$ \\
$\mathrm{ST}$ & $3.00-7.00$ & $12.50-25.00$ & $5.00-7.50$ \\
$\mathrm{~T}$ & $>7.00$ & $0.00-12.50$ & $7.50-10.00$ \\
\hline
\end{tabular}

The fundamental number was established on the basis of the number of autosomal arms (excluding the sex pair) as defined by Patton (1967). Karyograms of the mitotic chromosomes were prepared from photomicrographs. Individual chromosomal elements were cut from prints and paired with their presumed homologue.

\section{Results}

The chromosomal complement of $P$. $d$. felipensis from the States of Morelos and Estado de México comprises the following: 1 pair of (small) metacentric autosomes, 1 pair of (small) submetacentric autosomes, 13 pairs of (large to small) subtelocentric autosomes, 8 pairs (ranging from mid-size to small) of telocentric autosomes, a large subtelocentric X, and a small metacentric Y chromosome. The population of Cerro San Felipe, Oaxaca has the same chromosome set except for the submetacentric autosome which is missing, but it has two pairs of (small) metacentric autosomes. Both populations share the same $2 n=48$ and the same $\mathrm{fn}=76$. Sex chromosomes correspond to the typical XX/XY mammalian system and their karyotypes are structurally homologous.

A statistical analysis of each population was made based on 10 karyotypes in order to determine the individual lengths of the chromosomes and of chromosome arms $\mathrm{p}$ and $\mathrm{q}$. The position of the centromere was established according to Levan et al. (1964). Tables 1 and 2 show results of the analyses made in the two populations. Number 1 is from central Mexico (States of Mexico and 
Table 1. Relative length and classification of the chromosomes of Peromyscus difficilis felipensis from central Mexico (States of Mexico and Morelos)

\begin{tabular}{|c|c|c|c|c|c|c|}
\hline $\begin{array}{l}\text { Chromosome } \\
\text { pair }\end{array}$ & $\begin{array}{l}\text { Relative length } \\
\text { of } p\end{array}$ & $\begin{array}{l}\text { Relative length } \\
\text { of } q\end{array}$ & $P B=q / p$ & $\begin{array}{c}\mathrm{I} . \mathrm{C}=\mathrm{p} / \\
(\mathrm{p}+\mathrm{q})(100)\end{array}$ & $\begin{aligned} \mathrm{D}= & (\mathrm{PB}-1)(10) \\
& /(\mathrm{PB}+1)\end{aligned}$ & Classification \\
\hline 1 & 1.8625 & 2.41296875 & 1.29555369 & 43.57013016 & 1.285973967 & M \\
\hline 2 & 1.4459375 & 3.36140625 & 2.32472444 & 30.08496867 & 3.983006265 & SM \\
\hline 3 & 2.77140625 & 11.26390625 & 4.0643288 & 19.74506452 & 6.050987096 & $\mathrm{ST}$ \\
\hline 4 & 2.3896875 & 10.13125 & 4.23957107 & 19.0999472 & 6.180010561 & ST \\
\hline 5 & 2.03171875 & 11.19015625 & 5.50772899 & 15.37130098 & 6.925739805 & ST \\
\hline 6 & 1.82828125 & 9.58484375 & 5.24254337 & 16.02310221 & 6.795379557 & ST \\
\hline 7 & 1.77203125 & 8.84359375 & 4.99065338 & 16.69174917 & 6.661650166 & $\mathrm{ST}$ \\
\hline 8 & 1.775 & 8.2253125 & 4.63397887 & 17.75854216 & 6.448291568 & ST \\
\hline 9 & 1.6790625 & 7.34578125 & 4.37493021 & 18.60607608 & 6.278784784 & ST \\
\hline 10 & 1.5565625 & 6.530625 & 4.19554306 & 19.2505997 & 6.14988006 & ST \\
\hline 11 & 1.4296875 & 5.9396875 & 4.15453552 & 19.386521 & 6.122695801 & $\mathrm{ST}$ \\
\hline 12 & 1.4215625 & 5.5790625 & 3.92459881 & 20.29223859 & 5.941552282 & $\mathrm{ST}$ \\
\hline 13 & 1.32203125 & 5.295625 & 4.00567309 & 19.98331661 & 6.003336678 & ST \\
\hline 14 & 1.3275 & 5.36984375 & 4.04508004 & 19.82030667 & 6.035938666 & $\mathrm{ST}$ \\
\hline 15 & 1.15984375 & 4.75421875 & 4.09901657 & 19.61797803 & 6.076404395 & ST \\
\hline 16 & 0.65625 & 9.84265625 & 14.9983333 & 6.250202978 & 8.749959404 & $\mathrm{~T}$ \\
\hline 17 & 0.625 & 9.3171875 & 14.9075 & 6.286802439 & 8.742639512 & $\mathrm{~T}$ \\
\hline 18 & 0.625 & 7.8328125 & 12.5325 & 7.389796039 & 8.522040792 & $\mathrm{~T}$ \\
\hline 19 & 0.6125 & 6.77546875 & 11.0619898 & 8.300455326 & 8.339908935 & $\mathrm{~T}$ \\
\hline 20 & 0.55 & 6.189375 & 11.2534091 & 8.163819666 & 8.367236067 & $\mathrm{~T}$ \\
\hline 21 & 0.53125 & 5.895 & 11.0964706 & 8.266175253 & 8.346764949 & $\mathrm{~T}$ \\
\hline 22 & 0.50625 & 5.47215625 & 10.8091975 & 8.472919389 & 8.305416122 & $\mathrm{~T}$ \\
\hline 23 & 0.49375 & 4.87109375 & 9.86550633 & 9.221342699 & 8.15573146 & $\mathrm{~T}$ \\
\hline $\mathrm{X}$ & 2.45 & 15.67 & 6.39591837 & 13.5209713 & 7.29580574 & $\mathrm{ST}$ \\
\hline $\mathrm{Y}$ & 1.57 & 2.3025 & 1.46656051 & 40.54228535 & 1.891542931 & $\mathrm{M}$ \\
\hline
\end{tabular}

Table 2. Relative length and classification of chromosomes of Peromyscus difficilis felipensis from Oaxaca

\begin{tabular}{|c|c|c|c|c|c|c|}
\hline $\begin{array}{c}\text { Chromosome } \\
\text { pair }\end{array}$ & $\begin{array}{c}\text { Relative length } \\
\text { of } p\end{array}$ & $\begin{array}{c}\text { Relative length } \\
\text { of } \mathrm{q}\end{array}$ & $P B=q / p$ & $\begin{array}{c}I . C=p / \\
(p+q)(100)\end{array}$ & $\begin{aligned} \mathrm{D}= & (\mathrm{PB}-1)(10) \\
& /(\mathrm{PB}+1)\end{aligned}$ & Classification \\
\hline 1 & 2.3 & 2.999375 & 1.304076087 & 46.12800952 & 0.774398096 & M \\
\hline 2 & 2.5534375 & 3.818125 & 1.495288214 & 39.30616074 & 2.138767851 & $\mathrm{M}$ \\
\hline 3 & 3.6109375 & 12.815 & 3.548939853 & 21.59258704 & 5.681482593 & ST \\
\hline 4 & 3.2325 & 12.065625 & 3.732598608 & 21.70139185 & 5.65972163 & ST \\
\hline 5 & 2.5053125 & 12.2749375 & 4.899563428 & 17.43389356 & 6.513221288 & ST \\
\hline 6 & 2.279375 & 11.6246875 & 5.09994516 & 18.55033867 & 6.289932266 & ST \\
\hline 7 & 2.22625 & 9.970625 & 4.478663672 & 19.52722056 & 6.094555887 & $\mathrm{ST}$ \\
\hline 8 & 2.153125 & 9.2409375 & 4.291872279 & 20.06304098 & 5.987391805 & $\mathrm{ST}$ \\
\hline 9 & 2.116875 & 9.09625 & 4.29701801 & 19.86060314 & 6.027879372 & ST \\
\hline 10 & 2.0425 & 7.9665625 & 3.900397797 & 21.74319078 & 5.651361843 & $\mathrm{ST}$ \\
\hline 11 & 1.935 & 7.1225 & 3.680878553 & 20.42950558 & 5.914098884 & $\mathrm{ST}$ \\
\hline 12 & 1.625 & 6.08125 & 3.742307692 & 20.46220353 & 5.907559295 & ST \\
\hline 13 & 1.5375 & 6.115625 & 3.977642276 & 21.953603 & 5.6092794 & ST \\
\hline 14 & 1.491875 & 6.1325 & 4.110599078 & 21.22136152 & 5.755727696 & ST \\
\hline 15 & 1.3584375 & 5.3784375 & 3.959282264 & 21.28260345 & 5.74347931 & ST \\
\hline 16 & 0.6625 & 6.1053125 & 9.215566038 & 2.838751677 & 9.432249665 & $\mathrm{~T}$ \\
\hline 17 & 0.65 & 9.9171875 & 15.25721154 & 6.113914979 & 8.777217004 & $\mathrm{~T}$ \\
\hline 18 & 0.625 & 9.058125 & 14.493 & 6.087219699 & 8.78255606 & $\mathrm{~T}$ \\
\hline 19 & 0.625 & 7.57375 & 12.118 & 7.30998937 & 8.538002126 & $\mathrm{~T}$ \\
\hline 20 & 0.6125 & 6.7528125 & 11.025 & 8.014416522 & 8.397116696 & $\mathrm{~T}$ \\
\hline 21 & 0.6125 & 6.4671875 & 10.55867347 & 8.258033733 & 8.348393253 & $\mathrm{~T}$ \\
\hline 22 & 0.6 & 5.7496875 & 9.5828125 & 8.662099378 & 8.267580124 & $\mathrm{~T}$ \\
\hline 23 & 0.559375 & 5.4765625 & 9.790502793 & 9.572198744 & 8.085560251 & $\mathrm{~T}$ \\
\hline $\mathrm{X}$ & 3.738125 & 16.73 & 4.475505768 & 19.34640523 & 6.130718954 & $\mathrm{ST}$ \\
\hline $\mathrm{Y}$ & 1.64 & 2.17 & 1.323170732 & 43.0904933 & 1.381901339 & $\mathrm{M}$ \\
\hline
\end{tabular}




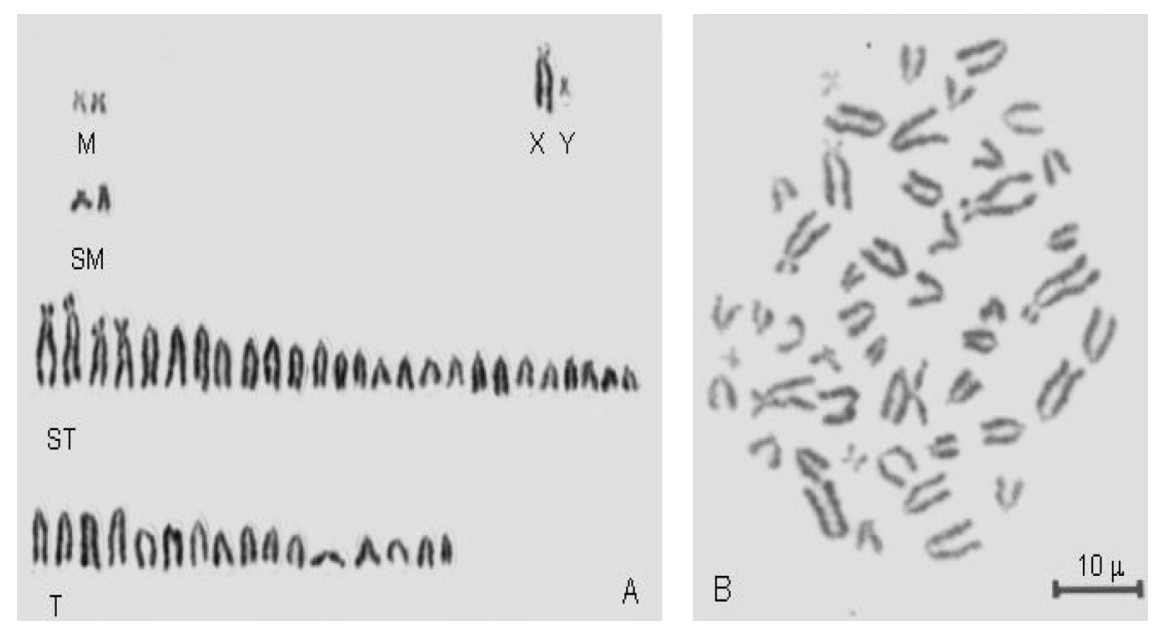

Fig. 1. Karyotype (A) and Metaphase (B) of Peromyscus difficilis felipensis from central Mexico.

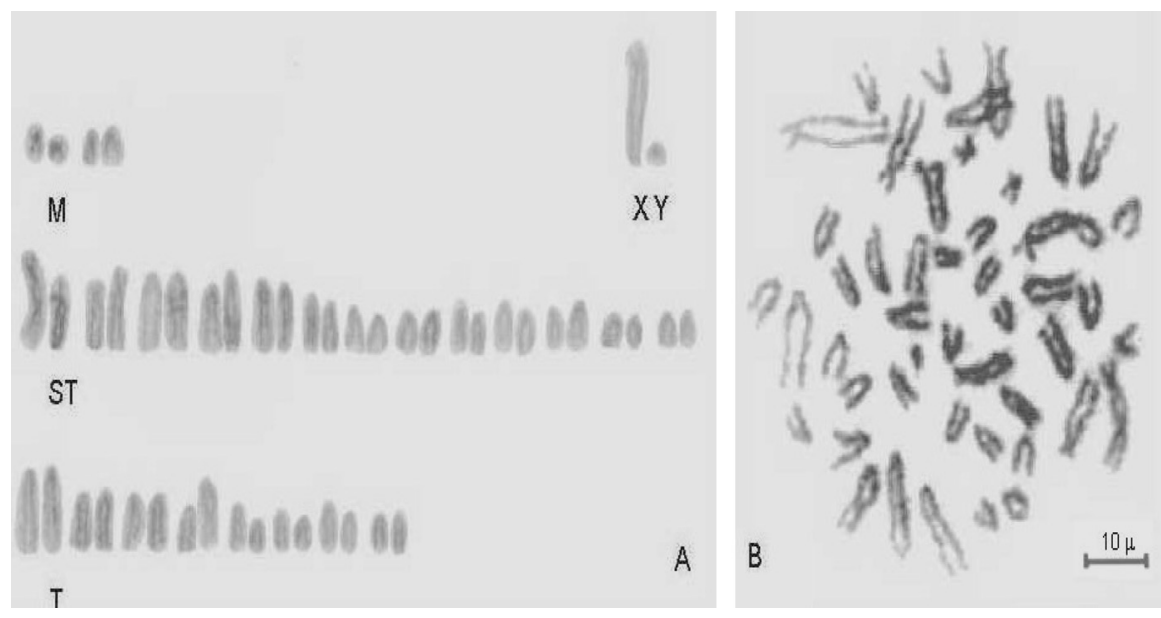

Fig. 2. Karyotype (A) and Metaphase (B) of Peromyscus difficilis felipensis from Oaxaca.

Idiogram (a)

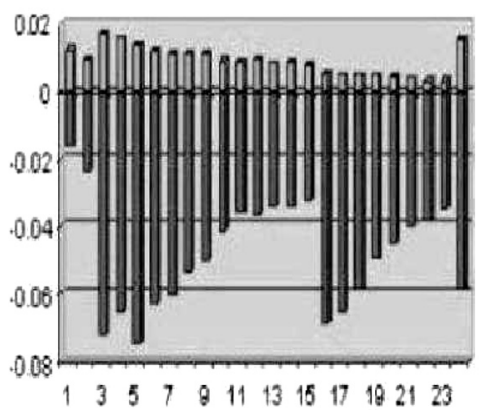

Idiogram (b)

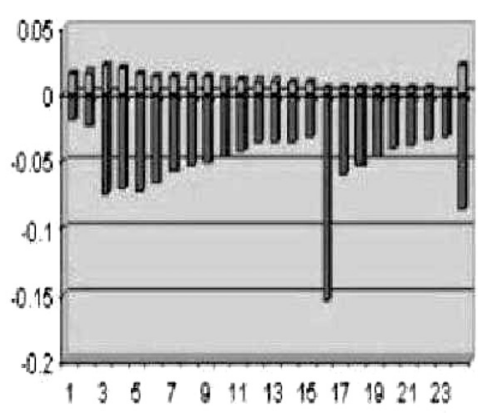

Fig. 3. Idiograms of Peromyscus difficilis felipensis from central Mexico (a) and from Oaxaca (b). 
Morelos) and number 2 is from Oaxaca. Figures 1 and 2 show the karyotypes and some of the mitosis used to describe each karyotype taken from the central population and the southeastern population from Oaxaca, respectively. Figure 3 shows the idiograms for both populations.

\section{Discussion}

Many of the most extreme examples of karyotypic variation are those encountered in the order Rodentia. With few exceptions, cytogeneticists have found a different karyotype for every rodent species investigated and, in many cases, have even found several different karyotypes within a species (Mascarello et al. 1974).

Our findings on the $2 n$ and fn of Peromyscus difficilis felipensis are similar to results reported for this species by Hsu and Arrighi in 1968. Our data indicate that this species show some intrasubspecific chromosomal polymorphism. We detected karyotypic polymorphism occurring between these two populations from central and southeastern Mexico. Peromyscus difficilis is one of the species in this genus which shows cytological polymorphism. Of the specimens previously reported (Diersing 1976, Lee et al. 1972, Hsu and Arrighi 1968, Arellano-Meneses et al. 2000), there is no "standard" karyotype for this species. If we compare it with $P$. d. amplus (another subspecies from central Mexico), we can see the differences (see next table).

\begin{tabular}{lccccccccc}
\hline \hline $\begin{array}{l}\text { P. d. amplus } \\
\text { 2M }\end{array}$ & $0 \mathrm{SM}$ & $8 \mathrm{ST}$ & $13 \mathrm{~T}$ & $\mathrm{X}=\mathrm{ST}$ & $\begin{array}{l}\mathrm{Y}= \\
\text { Small T }\end{array}$ & $2 n=48$ & $\mathrm{nf}=66$ & $\begin{array}{l}\text { Arellano et al. } \\
2000\end{array}$ \\
\hline $\begin{array}{l}\text { P. d. felipensis } \\
\begin{array}{l}\text { central Mexico } \\
\text { Oaxaca }\end{array}\end{array}$ & $1 \mathrm{M}$ & $1 \mathrm{SM}$ & $13 \mathrm{ST}$ & $8 \mathrm{~T}$ & $\mathrm{X}=\mathrm{ST}$ & $\begin{array}{l}\mathrm{Y}= \\
\text { Small M }\end{array}$ & $2 n=48$ & $\mathrm{nf}=76$ & Present study \\
\hline
\end{tabular}

The subspecie amplus has more telocentric chromosomes than difficilis. Chromosomal rearrangements such as fusions, pericentric inversions, and heterochromatin addition have been identified as the factors responsible for turning uni-armed chromosomes into biarmed chromosomes (Patton and Rogers 1993). Both the southern and northern populations could be derived from the same stock (possibly amplus-like), yet at present they denote similar adaptations by different segments of a single stock evolving in response to similar but new environmental conditions (Hoffmeister and de la Torre 1961).

Perhaps cytological characteristics are no more reliable than other morphological characters in this regard. Breeding experiments and morphometric studies must be performed in the future to provide answers to this problem and to determine the degree of isolation.

This heteromorphism could be interpreted as constituting a polimorphism within a continuum. The karyotypic differences and the geographic distribution of the various groups point to the beginning of a changing gene pool.

\section{References}

Arellano-Meneses, A. G., Hernández-Carvajal, L. A., Lira-Galera, I. E., Ruiz-Guzmán, G. and Müdespacher-Ziehl, C. 2000. Karyotypical Studies on Peromyscus difficilis amplus (Rodentia: Muridae). Cytologia 65: 25-28.

Baker, R. J. and Qumsiyeh, M. B. 1988. Methods in chiropteran mitotic chromosomal studies. In: Kunz, T. H. (ed.). Ecological and Behavioral Methods for the Study of Bats. Smithsonian Institution Press, Washington, D. C. pp. 425-434.

Carleton, M. D. 1989. Systematics and evolution. In: Kirkland, G. L., Jr. and Layne, J. N. (eds.). Advances in the study of Peromyscus (Rodentia). Texas Tech. University Press, Lubbock. VI+367.

Diersing, V. E. 1976. An analysis of Peromyscus difficilis from the Mexican-United States boundary area. Proc. Biol. Soc. 
of Washington 89: 451-466.

Hall, E. R. 1981. The Mammals of North America. Second Ed. John Wiley and Sons, New York. 2: 601-1181+90.

Hoffmeister, D. F. and de la Torre, L. 1961. Geographic variation in the mouse Peromyscus difficilis. J. Mamm. 42: 1-13.

Hsu, T. C. and Arrighi, F. E. 1968. Chromosomes of Peromyscus (Rodentia, Cricetidae). I. Evolutionary trends in 20 species. Cytogenetics, 7: 417-446.

Lee, M. R, Schmidly D. J. and Huheey, C. C. 1972. Chromosomal variation in certain populations of Peromyscus boylii and its systematic implication. J. Mamm. 53: 697-707.

Levan, A., Fredga, K. and Sandberg, A. A. 1964. Nomenclature for centromeric position on chromosomes. Hereditas 52: 201-220.

Mascarello, J. T., Stock, A. D. and Pathak, S. 1974. Conservatism in the arrangement of genetic material in rodents. J. Mamm. 55: 695-704.

Patton, J. L., 1967. Chromosome studies of certain pocket mice, genus Perognathus (Rodentia: Heteromyidae). J. Mamm. 48: 27-37.

— and Rogers, D. S. 1993. Cytogenetics. Pp. 236-258, In: Genoways, H. H. and Brown, J. H. (eds.). Biology of the Heteromyidae, Special Publication. The American Society of Mammalogists, 10: 1-719. 